\title{
Intensity-Dependent, Rapid Activation of Presynaptic Metabotropic Glutamate Receptors at a Central Synapse
}

\author{
Gautam B. Awatramani and Malcolm M. Slaughter \\ Department of Physiology and Biophysics and Department of Ophthalmology, State University of New York, Buffalo, \\ New York 14214
}

Synaptic signals from retinal bipolar cells were monitored by measuring EPSCs in ganglion cells voltage-clamped at -70 $\mathrm{mV}$. Spontaneous EPSCs were strongly suppressed by L-2amino-4-phosphonobutyrate (AP-4), an agonist at group III metabotropic glutamate receptors (mGluRs). Agonists of group I or II mGluRs were ineffective. AP-4 also suppressed ganglion cell EPSCs evoked by bipolar cell stimulation using potassium puffs, sucrose puffs, or zaps of current $(0.5-1 \mu \mathrm{A})$. In addition, AP-4 suppressed Off EPSCs evoked by dim-light stimuli. This indicates that group III mGluRs mediate a direct suppression of bipolar cell transmitter release. An mGluR antagonist, (RS)- $\alpha$ cyclopropyl-4-phosphonophenylyglycine (CPPG), blocked the action of AP-4. When bipolar cells were weakly stimulated,
AP-4 produced a large suppression of the EPSC, but CPPG alone had little effect. Conversely, when bipolar cells were strongly stimulated, CPPG produced an enhancement of the EPSC, but AP-4 alone had little effect. This indicates that endogenous feedback regulates bipolar cell transmitter release and that the dynamic range of the presynaptic metabotropic autoreceptor is similar to that of the postsynaptic ionotropic receptor. Furthermore, the feedback is rapid and intensitydependent. Hence, concomitant activation of presynaptic and postsynaptic glutamate receptors shapes the responses of ganglion cells.

Key words: synaptic transmission; retina; bipolar cell; AP-4; CPPG; ganglion cell
In a variety of systems, synaptic release is altered by the activation of presynaptic metabotropic glutamate receptors (mGluRs) (for review, see Miller, 1998; Anwyl, 1999). These receptors suppress transmitter release by affecting calcium or potassium channels (Saugstad et al., 1996; Takahashi et al., 1996) or by a direct action on the proteins involved in transmitter release (Scanziani et al., 1995). They can also enhance transmitter release by modulation of calcium release from internal stores (Peng, 1996; Cochilla and Alford, 1998).

To date, eight mGluRs have been cloned and divided into three groups based on sequence homology and pharmacology (Pin and Duvoisin, 1995). Different subcellular distributions of mGluRs have been reported, suggesting they have different functions at the synapse. Group I receptors often appear restricted to the postsynaptic terminal (Martin et al., 1992; Koulen et al., 1997; Lujan et al., 1997), although exceptions have been noted (Cochilla and Alford, 1998). Group II and III receptors are generally presynaptic (Shigemoto et al., 1997). Group II receptors are found to have a diffuse distribution in the periterminal regions of the membrane (Petralia et al., 1996; Shigemoto et al., 1996; Yokoi et al., 1996; Lujan et al., 1997; Shigemoto et al., 1997). Localization outside of the synaptic active zone has led to the hypothesis that these receptors are activated only by prolonged and enhanced synaptic stimulation that produces glutamate "spillover" to perisynaptic sites (Asztely et al., 1997; Scanziani et al., 1997). Consistent with this scheme, group II-mediated inhibition is more apparent when the glutamate concentration in the cleft is

Received Aug. 29, 2000; revised Oct. 30, 2000; accepted Nov. 3, 2000.

This work was supported by National Eye Institute Grant EY05725. We thank Dr. Asbed Keleshian for his critical comments on this manuscript.

Correspondence should be addressed to Malcolm M. Slaughter, Department of Physiology and Biophysics, 124 Sherman Hall, 3435 Main Street, Buffalo, NY 14214. E-mail: mslaught@buffalo.edu.

Copyright (C) 2001 Society for Neuroscience $0270-6474 / 01 / 210741-09 \$ 15.00 / 0$ artificially raised by pharmacological blockade of glutamate transporters (Maki et al., 1994; Scanziani et al., 1997; Dube and Marshall, 2000).

In contrast, group III receptors are selectively localized near the transmitter release site (Brandstätter et al., 1996; Li et al., 1997; Shigemoto et al., 1997), suggesting that these mGluRs may serve as autoreceptors activated exclusively by synaptically localized glutamate release.

The bipolar to ganglion cell synapse in the retina is well suited to examine the properties of metabotropic glutamate receptors. This synapse can be activated by natural or artificial stimuli, and the release properties of the synapse are graded, robust, and well characterized. We found that the output of this synapse is regulated by mGluR-negative feedback, that the autoreceptor can be rapidly activated $(<20 \mathrm{msec}$ ), and that the dynamic range of the feedback is similar to that of the feedforward synapse.

\section{MATERIALS AND METHODS}

Slice preparation. Larval tiger salamanders (Ambystoma tigrinum) were obtained from Kons Scientific (Germantown, WI) and Charles Sullivan (Nashville, TN) and were kept in tanks maintained at $4^{\circ} \mathrm{C}$ on a $12 \mathrm{hr}$ light/dark cycle. Retinal slices were prepared as described by Wu (1987). All procedures were performed in accordance with the United States Animal Welfare Act and the NIH Guide for the Care and Use of Laboratory Animals (publication \#85-23) and were approved by the Animal Care Committee of the State University of New York. In dim red light, animals were decapitated and double-pithed; eyes were enucleated. The retina was removed from the eyecup, placed on a $0.45 \mu \mathrm{m}$ pore membrane filter (Millipore, Bedford, MA) with the photoreceptor side down, and subsequently sliced at $150-250 \mu \mathrm{m}$ intervals using a tissue slicer (Stoelting, Woods Lane, IL). A single slice was then transferred to the recording chamber and viewed under infrared light using a CCD camera attached to an upright Olympus IMT2 fluorescent microscope, equipped with a $40 \times$ water-immersion lens (Zeiss, Thornwood, NY).

In a few experiments, a reduced retinal slice preparation was used, containing only cell bodies in the amacrine and ganglion cell layers along with an intact inner plexiform layer (IPL). Slices were made with the 


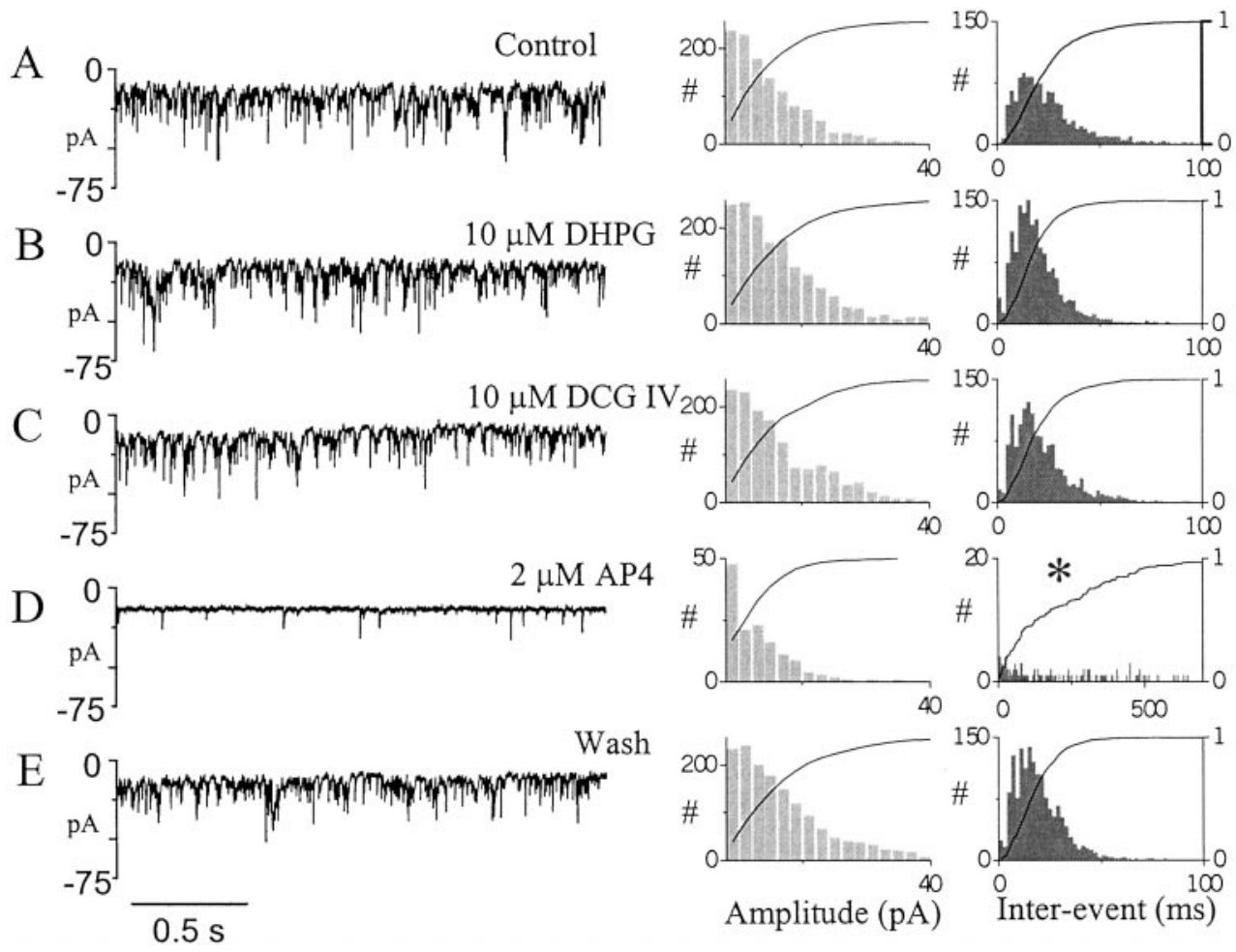

Figure 1. Effects of mGluR agonists on spontaneous EPSCs in ganglion cells. The ganglion cell was voltage-clamped at -70 $\mathrm{mV}$ ( approximate $\mathrm{E}_{\mathrm{Cl}}$ ). The spontaneous EPSCs (left) and a histogram and cumulative distribution of the amplitudes (middle) and of the interevent durations (right) of the spontaneous events are shown in the presence of control Ringer's solution $(A)$, the group I mGluR agonist DHPG $(B)$, the group II receptor agonist DCG-IV (C), the group III receptor agonist AP-4 $(D)$, and washout of drugs $(E)$. The asterisk in $D$ (right) indicates that the cumulative distribution was statistically different from control $\left({ }^{*} p<0.005\right.$ by the Kolmogorov-Smirnov test). vitreal side facing the filter paper, and a perfusion pipette was placed behind the filter paper to direct the flow of Ringer's solution from the ganglion cell layer to the photoreceptor layer. Next, SDS detergent (1-5\%) was applied to the outer retina. This dissolved away the outer retinal layers while the perfusion system blew the debris away, protecting the inner retina.

The slice was continually bathed with control Ringer's solution containing (in mM): $111 \mathrm{NaCl}, 2.5 \mathrm{KCl}, 1.8 \mathrm{CaCl}_{2}, 1 \mathrm{MgCl}_{2}, 10$ dextrose, and 5 HEPES buffered to $\mathrm{pH}$ 7.8. Using a gravity-fed perfusion system, Ringer's solution could be exchanged with drug-containing solutions within $5-10 \mathrm{sec}$. $S$-3,5-Dihydrophenylglycine (DHPG), $\left(2 S, 1^{\prime} R, 2^{\prime} R, 3^{\prime} R\right)-2-\left(2^{\prime}-3^{\prime}\right.$-dicarboxy cyclo-propyl)-glycine (DCG-IV), L-2-amino-4-phosphonobutyrate (AP-4), and $(R S)$ - $\alpha$-cyclopropyl-4-phosphonophenylglycine (CPPG) were obtained from Tocris Cookson (Ballwin, MO). All other chemicals were obtained from Sigma (St. Louis, MO).

Whole-cell patch-clamp recordings. Recordings were made from neurons in the ganglion cell layer of the retinal slice preparation. All data were from neurons that exhibited transient responses at light onset and/or offset. Neurons were clamped at $-70 \mathrm{mV}$ to isolate EPSCs. This was confirmed by testing the effect of GABA, which reversed at this potential (W. Shen, State University of New York, Buffalo, NY personal communication). Whole-cell recordings were made using $\sim 5 \mathrm{M} \Omega$ electrodes containing (in mM): $105 \mathrm{~K}$-gluconate, $5 \mathrm{KCl}, 1 \mathrm{MgCl}_{2}, 1$ BAPTA, 10 HEPES, 4 ATP $\mathrm{Na}_{2}, 0.5 \mathrm{GTP} \mathrm{Na}_{3}$, and $1 \%$ Lucifer yellow. The $\mathrm{pH}$ was adjusted to 7.4 with $\mathrm{KOH}$. The voltage- and current-clamp recordings were made with an Axopatch 200B amplifier (Axon Instruments, Foster City, CA). Analog signals were filtered at $1 \mathrm{kHz}$ and sampled at $2 \mathrm{kHz}$ with the Digitadata 1200 analog-to-digital board (Axon Instruments). Clampex8 (pClamp8; Axon instruments) was used to control the voltage command outputs, acquire data, and trigger the light stimulus. The currents and voltages shown are raw data, and electrode junctional potentials and access resistances were not corrected.

Stimulation paradigms. Responses in ganglion cells were evoked by light stimuli or by artificially stimulating bipolar cells. For light stimulation, a red Stanley light-emitting diode (LED) that emitted a range of $\sim 10^{2}-10^{4}$ photons per square micrometer per second at $620 \mathrm{~nm}$ was used (Nygaard and Frumkes, 1982). A 1-2 sec light stimulus was presented every $30 \mathrm{sec}$. In other experiments, bipolar cells were directly stimulated in one of three ways. Puffs $(50 \mathrm{msec})$ of $100 \mathrm{mM} \mathrm{K}^{+}$in the outer plexiform layer (OPL) or puffs $(1 \mathrm{sec})$ of hyperosmotic $(0.5 \mathrm{M})$ sucrose in the IPL (Yu and Miller, 1995) were delivered through a puff pipette positioned $\sim 20 \mu \mathrm{M}$ above the slice preparation. Alternatively, short pulses $(1 \mathrm{msec})$ of current were delivered through an electrode filled with Ringer's solution that was placed directly into the OPL, above the patched ganglion cell. The pulses were generated with a constant-current stimulator (Grass S48 with stimulus isolation unit PSIU6; Grass Instruments, West Warwick, RI).

Analysis. Spontaneous activity in ganglion cells was analyzed using a mini analysis program (Synaptosoft, Leonia, NJ). All other data were analyzed using Clampfit 8 (pClamp8; Axon Instruments).

\section{RESULTS}

\section{Group III mGluR activation suppresses spontaneous synaptic activity in ganglion cells}

In the dark, spontaneous activity is observed in ganglion cells. This activity has been observed and characterized in third-order cells of the salamander (Taylor et al., 1995; Gao and Wu, 1999), turtle (O'Donovan, 1999), and mouse (Tian et al., 1998) retina. Here we assessed the ability of various mGluRs to modulate spontaneous EPSCs in ganglion cells voltage-clamped at -70 $\mathrm{mV}$. Group I receptors are selectively activated by DHPG (Tauchi et al., 1984; Shen et al., 1995), group II receptors by DCG-IV (Hayashi et al., 1993), and group III receptors by AP-4 (Tanabe et al., 1993).

Application of group I and II mGluR-specific agonists did not significantly affect spontaneous activity. In contrast, group III mGluR activation suppressed spontaneous currents in ganglion cells. Figure $1 A$ depicts the spontaneous currents in a transient On-Off ganglion cell recorded in a dark-adapted slice preparation. The spontaneous activity was generated by excitatory glutamatergic input from bipolar cells because the ganglion cell was voltage-clamped close to the chloride reversal potential $(-70$ $\mathrm{mV})$. Application of $10 \mu \mathrm{M}$ DHPG or $10 \mu \mathrm{M}$ DCG-IV, agents that are known to specifically activate groups I and II mGluRs in third-order cells in this preparation (Shen and Slaughter, 1998), did not significantly affect spontaneous activity (Fig. $1 B, C$ ). In contrast, activating group III mGluRs, using AP-4, dramatically suppressed the spontaneous currents in a reversible manner (Fig. 


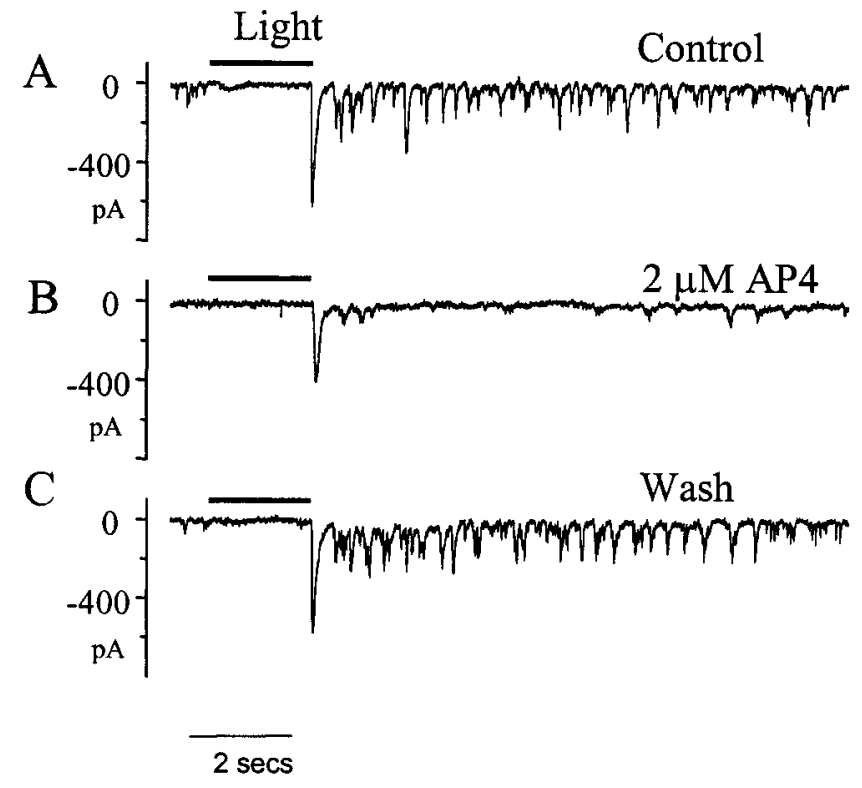

Figure 2. Group III mGluRs modulate the Off pathway. The lightevoked EPSC in an Off ganglion cell voltage-clamped at $-70 \mathrm{mV}\left(\mathrm{E}_{\mathrm{Cl}}\right)$ in control Ringer's solution $(A)$, in the presence of AP-4 $(B)$, and when returned to control Ringer's solution $(C)$. The solid bar represents a $2 \mathrm{sec}$ red-light stimulus.

$1 D, E)$. In the presence of AP-4, the interval between two events was greatly protracted (mean \pm SD interval, $208 \pm 210 \mathrm{msec}$; note change of scale in abscissa) compared with control $(25 \pm 17$ msec). However, the mean amplitude and amplitude distribution of the remaining EPSCs were not significantly changed (mean amplitude was $13 \pm 6 \mathrm{pA}$ in AP-4 compared with $15 \pm 7 \mathrm{pA}$ in control Ringer's solution). The decrease in frequency and not amplitude are indicative of a presynaptic site of action. Furthermore, AP-4 application did not affect the current responses elicited by pressure injecting glutamate directly onto the ganglion cell ( $n=4$; data not shown). Together, these observations suggest that group III mGluRs modulate bipolar to ganglion cell communication and that this regulation occurs presynaptic to the ganglion cell.

\section{mGluR-III suppresses output at the axon terminal of Off bipolar cells}

An objective was to determine the site of action of AP-4. It is known that AP-4 suppresses the light activity of On bipolar cells and drives these cells close to their dark membrane potential (Shiells et al., 1981; Slaughter and Miller, 1981). AP-4 does not suppress Off bipolar light responses. Although the above results suggest that AP-4 was decreasing the output of bipolar cells, it was not clear (1) whether it was acting on On or Off bipolar cells or both and (2) in the case of On bipolar cells, whether it was suppressing spontaneous activity because of the activation of mGluRs at the dendritic or at the axonal terminals.

Evidence that AP-4 affects the output of Off bipolar cells came from evaluation of dark currents of Off ganglion cells $(n=4)$. At the onset of light, when Off bipolar cell transmitter release decreases and On bipolar cell release increases, there was a loss of excitatory current and a concomitant cessation of spontaneous activity in these ganglion cells (Fig. 2). At light offset, there was a transient EPSC followed by sustained asynchronous activity. This indicates that Off ganglion cells receive inputs predomi-

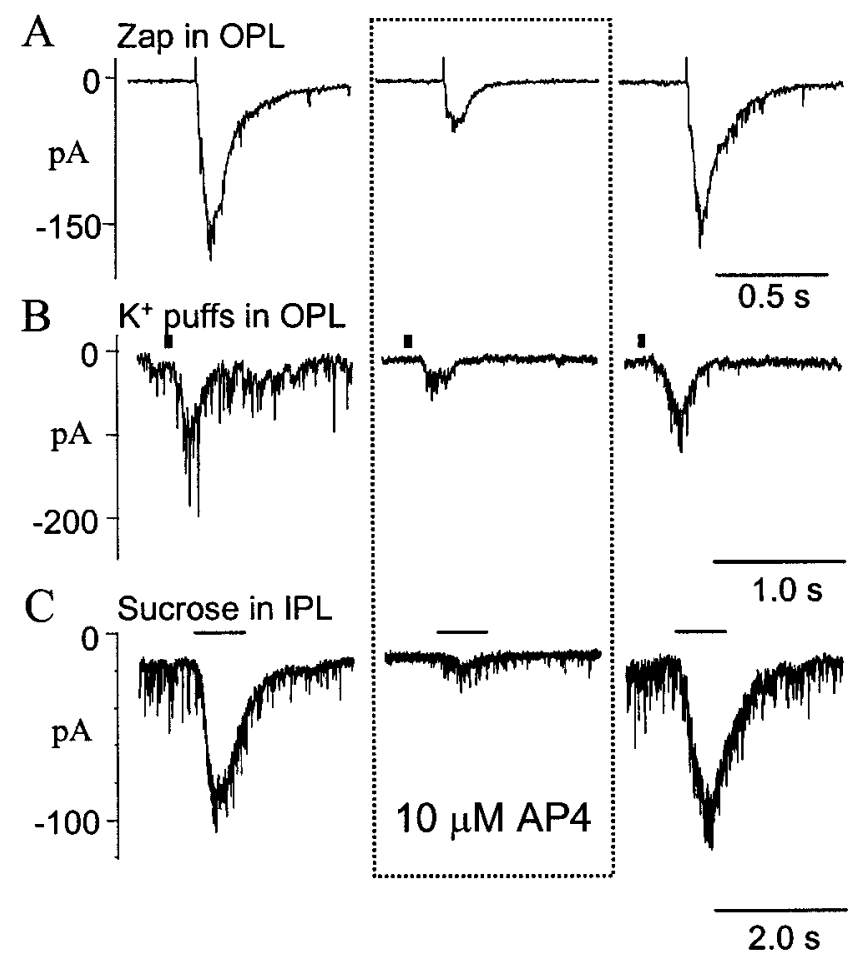

Figure 3. Effects of AP-4 on the monosynaptic responses in ganglion cells evoked by artificially stimulating bipolar cells. Responses evoked by electrical pulses $(2.5 \mu \mathrm{A}, 1 \mathrm{msec})$ delivered in the OPL $(A), 100 \mathrm{mM} \mathrm{K}^{+}$ puffs $(50 \mathrm{msec})$ in the OPL $(B)$, and $0.5 \mathrm{M}$ sucrose puffs $(1 \mathrm{sec})$ in the IPL $(C)$. Responses are recorded $(A-C)$ in control Ringer's solution (left), in the presence of AP-4 (middle), and after the mGluR agonist was washed out (right). The stimulus artifact preceding the EPSC indicates when the zap was delivered $(A)$. The solid bar above the traces $(B, C)$ represents duration of the stimulus. Neurons were voltage-clamped at $-70 \mathrm{mV}$ $\left(\mathrm{E}_{\mathrm{Cl}}\right)$.

nantly from Off bipolar cells. AP-4 depressed the Off activity in these ganglion cells. A total of $10 \mu \mathrm{M}$ AP-4 had little effect at light onset yet decreased the transient EPSC at light offset. Even more striking was the suppression of the asynchronous currents that followed the transient Off EPSC (Fig. 2). Because of the low occurrence of this cell type $(<10 \%)$, they were not studied more extensively. However, the results demonstrate that AP-4 can modulate the Off pathway. Because AP-4 does not suppress the light responses of Off bipolar cells, this implies that AP-4 is acting at the Off bipolar cell axonal terminals.

\section{mGluR-III suppression of release from bipolar cells is intensity-dependent}

Another method of evaluating regulation of the bipolar cell to ganglion cell synapse is to directly stimulate bipolar cells while recording EPSCs in ganglion cells. This avoids the complications produced by the action of AP-4 on other neurons or the effect of AP-4 at the dendritic terminals of On bipolar cells. We used several methods to stimulate bipolar cells. Glutamate release from bipolar cells was stimulated by puffs of $100 \mathrm{mM} \mathrm{K}^{+}$in the OPL. Although $\mathrm{K}^{+}$puffs in the OPL depolarize all cells in the vicinity, the direct effects on bipolar cells probably override synaptic input from photoreceptors or horizontal cells. Potassium puffs in the OPL produced EPSCs in ganglion cells. In three of four ganglion cells tested, mGluR activation caused a suppression of the $\mathrm{K}^{+}$puff-stimulated EPSCs. In the other ganglion cell, there was no significant effect on the $\mathrm{K}^{+}$-evoked EPSCs. Figure $3 B$ 


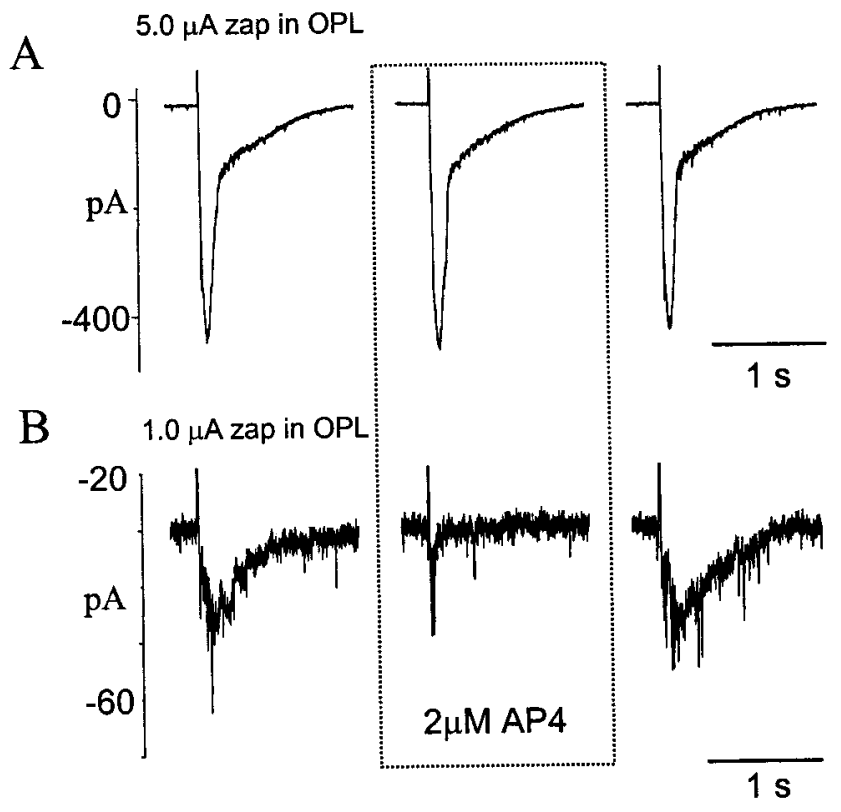

Figure 4. Differential effect of mGluR activation on responses evoked by strong and weak stimuli. $A$, A $5.0 \mu \mathrm{A}$ current pulse $(1 \mathrm{msec})$ was delivered to the OPL, and the current responses were recorded in a voltage-clamped ganglion cell. $B$, Weaker current injections of $1.0 \mu \mathrm{A}$ elicited smaller responses in the ganglion cell. EPSCs in this cell (for $A, B$ ) are shown in control Ringer's solution (left), in the presence of AP-4 (middle), and after the agonist has been washed out (right). Neuron was voltage-clamped at $-70 \mathrm{mV}\left(\mathrm{E}_{\mathrm{Cl}}\right)$.

shows one such recording in which $10 \mu \mathrm{M}$ AP-4 reversibly reduced the synaptic current evoked.

Bipolar cells were also stimulated by puffing hyperosmotic sucrose $(0.5 \mathrm{M})$ solution on the inner plexiform layer. The advantage of this method is that photoreceptors are not stimulated and the responses only reflect the properties of bipolar cell axonal terminals ( $\mathrm{Yu}$ and Miller, 1995). Application of AP-4 reversibly inhibited the sucrose-evoked EPSCs in four of six cells tested (Fig. $3 C$ ). In the other two cells tested, AP-4 slightly enhanced the sucrose-evoked responses

To stimulate the bipolar cells in a more controlled manner, an electrical method of stimulation (zap) was used (Higgs and Lukasiewicz, 1999). This method required injecting brief current pulses $(1 \mathrm{msec})$ in the OPL through an electrode filled with Ringer's solution. Using this stimulation protocol, glutamate release from bipolar cell terminals was controlled by varying the amplitude of the stimulus current. Injecting currents incrementally from 0.5 to $5 \mu \mathrm{A}$ caused a corresponding increase in EPSCs observed in ganglion cells. The increased EPSC amplitude probably arose from a greater depolarization of bipolar cells and from a larger number of bipolar cells being stimulated. Consistent with the data from the $\mathrm{K}^{+}$and sucrose protocols, AP-4 suppressed the zap-evoked (2.5 $\mu \mathrm{A}, 1 \mathrm{msec}$ ) currents (Fig. $3 A$ ).

In some ganglion cells, AP-4 did not affect the zap-evoked currents. In these cases, the stimulating current was reduced in amplitude. Weaker stimuli produced smaller currents in ganglion cells that were suppressed by AP-4. For example, Figure $4 A$ shows a zap-evoked synaptic potential in a ganglion cell that was not suppressed by AP-4. This ganglion cell response was produced by a $5 \mu \mathrm{A}$ zap in the outer plexiform layer. When the zap was reduced to $1 \mu \mathrm{A}$, the smaller EPSC was suppressed by AP-4 (Fig. 4B). In general, AP-4 suppression was inversely related to
A
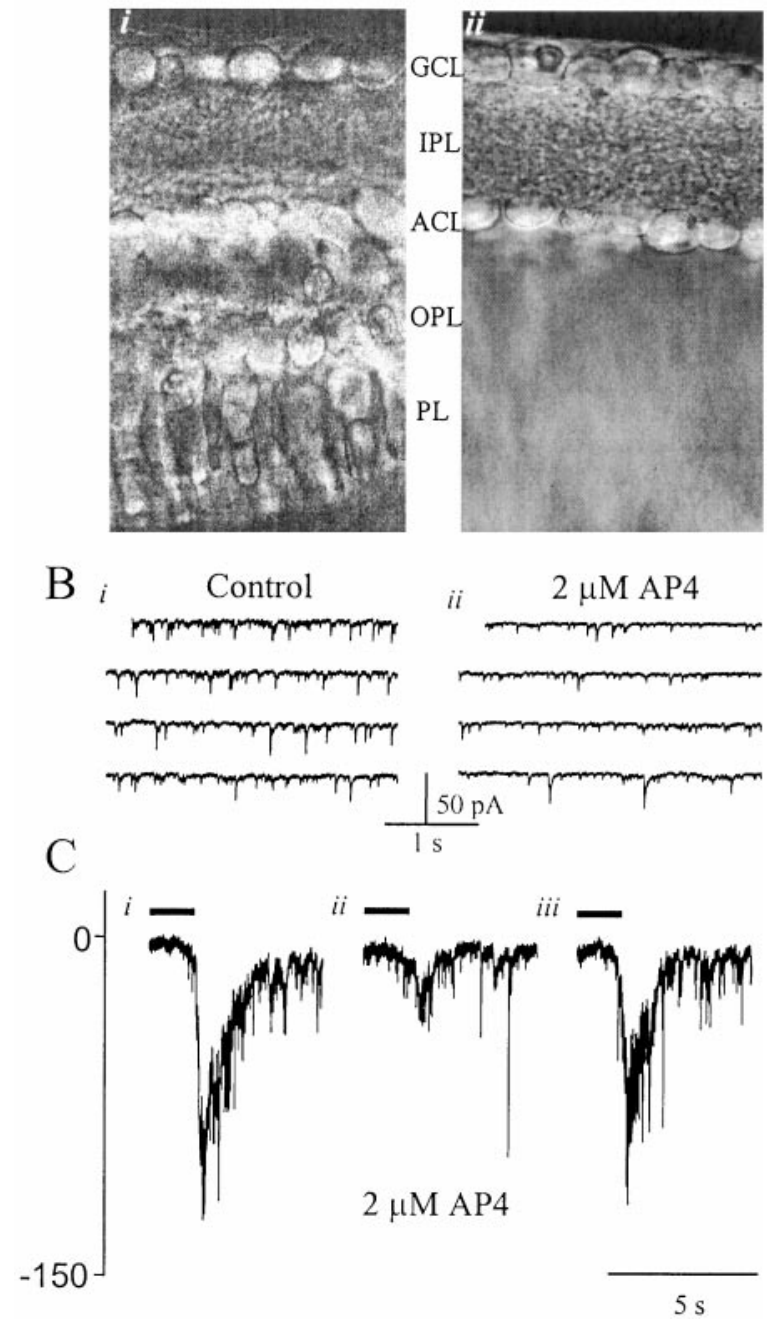

Figure 5. mGluRs inhibit synaptic transmission in the reduced, innerretinal preparation. $A$, Photomicrographs of the retinal slice before $(i)$ and after (ii) the outer retina was removed (see Materials and Methods). $B$, Voltage-clamp recording of the spontaneous activity from a ganglion cell in a reduced slice preparation in control Ringer's solution $(i)$ and in the presence of $2 \mu \mathrm{M}$ AP-4 (ii). $C$, Sucrose-evoked $(0.5 \mathrm{M}, 1 \mathrm{sec})$ EPSCs recorded from another ganglion cell in a reduced preparation in control Ringer's solution ( $i$ ), in the presence of $2 \mu \mathrm{M} \mathrm{AP-4} \mathrm{(ii),} \mathrm{and} \mathrm{after} \mathrm{the} \mathrm{drug}$ was washed out (iii). The dark bars above the traces show when the sucrose was applied. Neurons were voltage-clamped at $-70 \mathrm{mV}\left(\mathrm{E}_{\mathrm{Cl}}\right)$.

the strength of the zap stimulus. On average, AP-4 reduced the EPSC peak amplitude evoked by weak stimulation $(0.5-1 \mu \mathrm{A}, 1$ msec) by $81 \pm 10 \%(n=6 ; p<0.005)$; however, the EPSC peak amplitude evoked by moderate to strong stimuli (3-5 $\mu \mathrm{A}, 1 \mathrm{msec})$ was only reduced by $29 \pm 8 \%(n=12 ; p<0.05)$. Hence, exogenous activation of mGluRs was much more effective in suppressing weak synaptic inputs to ganglion cells.

\section{Effects of AP-4 in the isolated inner retina}

To demonstrate that AP-4 directly acted at the axonal terminals of bipolar cells, we evaluated its actions in a reduced, innerretinal preparation. After slices were secured in the recording chamber (Fig. 5A, left), the outer retina was carefully removed (see Materials and Methods). After the inner retina had been isolated (Fig. $5 A$, right), the effect of AP-4 on spontaneous and evoked EPSCs in ganglion cells was tested. Spontaneous EPSCs 
recorded in ganglion cells could be completely blocked by $10 \mu \mathrm{M}$ 2,3-dihydroxy-6-nitro-7-sulfamoylbenzo[f]quinoxaline, a glutamate receptor antagonist (data not shown), suggesting that they originated from bipolar cell axonal terminals. Figure $5 B$ is an example of the spontaneous currents observed in a ganglion cell voltage-clamped at $-70 \mathrm{mV}$. As in the whole-slice preparation, application of $2 \mu \mathrm{M} \mathrm{AP-4}$ decreased the frequency of these spontaneous currents (Fig. 5B). Similar observations were made in five other ganglion cells.

Next, we examined the effects of AP-4 on evoked synaptic release from bipolar terminals in the reduced, inner-retinal preparation. When hyperosmotic sucrose was puffed on the IPL, robust EPSCs were observed in ganglion cells, as illustrated in Figure 5C. Application of $2 \mu \mathrm{M}$ AP-4 reversibly reduced the sucrose-evoked EPSCs by $61 \pm 15 \%(n=4)$ (Fig. $5 C)$. Together, these data confirmed previous results that implied that mGluR activation suppressed synaptic release from bipolar cell axonal terminals.

\section{Endogenous activation of mGluRs}

We subsequently examined the role of endogenous mGluR activation in modulating synaptic transmission using an mGluR antagonist, CPPG (Jane et al., 1996; Awatramani and Slaughter, 2000). CPPG antagonized and reversed the effects of exogenously applied AP-4. For example, Figure $6 A$ shows a recording from a ganglion cell in which the application of $2 \mu \mathrm{M}$ AP-4 diminished the zap-evoked response. A total of $200 \mu \mathrm{M}$ CPPG blocked the suppression produced by AP-4, enhancing the EPSC relative to control. In a set of eight cells tested, AP-4 reduced the mean EPSC produced by a zap. In six of these eight ganglion cells, 200 $\mu \mathrm{M}$ CPPG not only blocked this action of $2 \mu \mathrm{M}$ AP-4 but also produced an enhancement of the EPSC $(118 \pm 22 \%$ of control; $p<0.05$ ) (Fig. 6B). In the two other ganglion cells, both AP-4 and CPPG produced a suppression of the zap-evoked EPSC. The finding in six cells that CPPG enhanced the zap-evoked responses in ganglion cells suggests that glutamate released from bipolar cell terminals activates metabotropic autoreceptors, thereby suppressing transmitter release from the axonal terminals.

\section{Modulation of the Off response in ganglion cells by group III mGluRs}

Because the activation of mGluRs was found to influence bipolar cell output, we subsequently examined the ramifications on the light-driven synaptic responses of ganglion cells. When examining the light-evoked EPSC in ganglion cells, the action of bipolar cells cannot be dissociated from the rest of the retinal circuitry. The effects of applying mGluR agonists and antagonists include their actions in both the inner and outer retina. In the outer retina, applying AP-4 completely eliminates the On bipolar cell response to light but spares the responses of Off bipolar cells. As a result, the study of mGluR regulation of light responses is limited to the Off system. Because mGluR activation differentially suppressed EPSCs to weak and strong zaps, we compared the effects of AP-4 on Off responses evoked by dim- and bright-light stimuli. Figure $7 A$ shows a voltage-clamp recording of light-evoked EPSCs in an On-Off ganglion cell held near the chloride reversal potential $(-70 \mathrm{mV})$. The On and Off EPSCs were elicited by $1 \mathrm{sec}$ light stimuli of increasing intensity. When AP-4 was applied, the On response was blocked at all light intensities. This is because of the suppression of the On bipolar light response produced by activation of dendritic mGluRs. The Off responses to the dimmer stimuli were suppressed. As the stimulus was made brighter, the
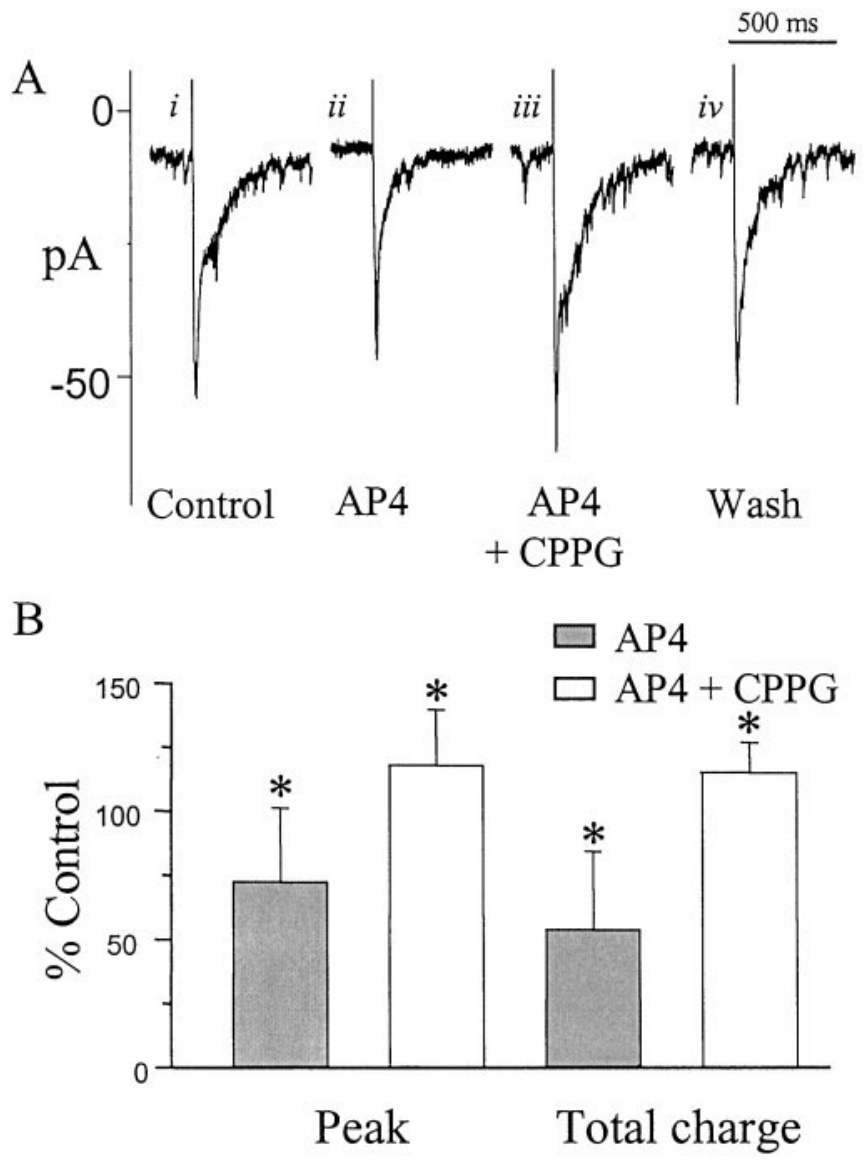

Figure 6. Endogenous activation of mGluRs suppresses bipolar cell output. $A$, Zap-evoked ( $5 \mu \mathrm{A})$ EPSCs in ganglion cells voltage-clamped at $-70 \mathrm{mV}$ in control Ringer's solution (i), in the presence of $2 \mu \mathrm{M} \mathrm{AP}-4$ (ii), in the presence of $2 \mu \mathrm{M} \mathrm{AP}-4$ and $200 \mu \mathrm{M} \mathrm{CPPG} \mathrm{(iii),} \mathrm{and} \mathrm{after} \mathrm{the} \mathrm{drugs}$ were washed out $(i v) . B$, The mean \pm SD peak EPSC amplitude and the total EPSC charge caused by the application of AP-4 are represented by gray columns. The CPPG-mediated enhancements of the peak and the total charge are indicated by white columns $\left({ }^{*} p<0.05\right)$.

Off response became less suppressed by AP-4 application. With a still brighter light stimulus, the Off response in the presence of AP-4 was slightly enhanced compared with control. The AP-4 suppression of weak Off responses is similar to its effect on zap-induced EPSCs in ganglion cells. However, the enhancement of Off responses to bright-light stimuli does not have a correlate in the zap experiments (see Discussion).

In current-clamp mode, effects of AP-4 on the Off responses were similar, but the inhibition was less pronounced. Figure $7 B$ shows voltage responses in the same cell. Once again, application of AP-4 completely blocked the On responses at all light intensities and suppressed the Off EPSPs to dimmer light stimuli. However, in dim light, the AP-4 suppression of the Off EPSP was less evident than the suppression of the Off EPSC. Voltage-gated conductances play an important role in shaping ganglion cell responses (Diamond and Copenhagen, 1995) and may mask changes in inputs. This might also explain why previous intracellular recordings revealed virtually no effect of AP-4 on Off responses in ganglion cells. Thus, the EPSC seems to be a better gauge of the actions of AP-4.

The effects of AP-4 on Off EPSCs from 10 cells are summarized in Figure $7 C$. The peak Off EPSC amplitudes are plotted as a function of light intensity in control conditions (Fig. $7 C$, filled 


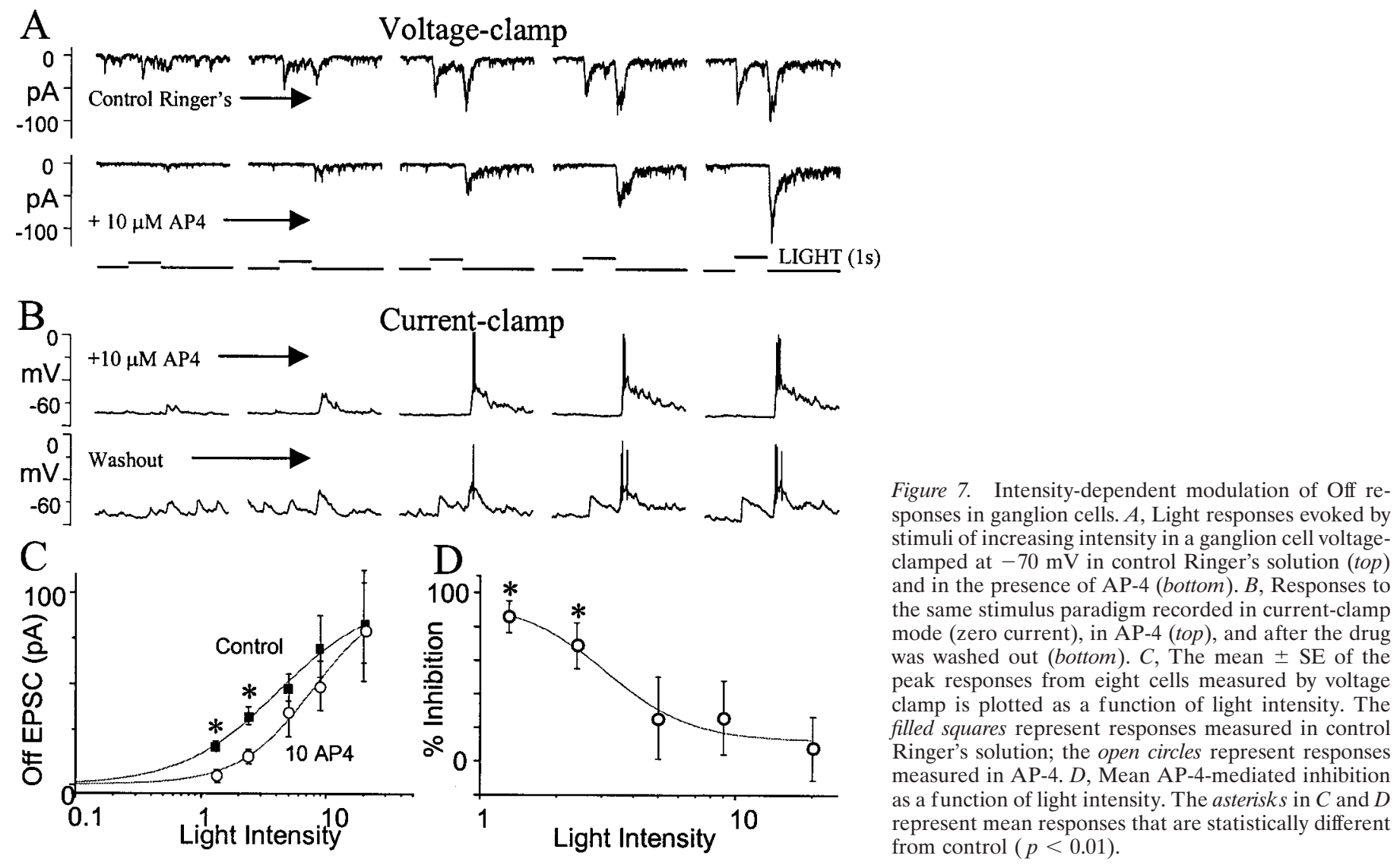

squares) and in the presence of AP-4 (Fig. 7C, open circles). With the dimmest light stimulus, AP-4 suppressed the responses by an average of $86 \pm 10 \%$. Response amplitudes were much less suppressed when the stimulus was $1 \log$ unit brighter. In six ganglion cells, AP-4 enhanced the Off EPSCs by $25 \pm 14 \%$; in the other four cells, the EPSCs were suppressed by $35 \pm 13 \%$ compared with control. Figure $7 D$ shows the inverse relationship between light intensity and the suppression caused by AP-4.

To test the possibility that mGluRs acted by regulating inhibitory input to bipolar cells, we examined the effects of AP-4 on ganglion cell responses in the presence of ionotropic GABA and glycine receptor antagonists $(100 \mu \mathrm{M}$ picrotoxin and $10 \mu \mathrm{M}$ strychnine). Figure 8 shows the effects of AP-4, in the presence of picrotoxin and strychnine, on ganglion cell On and Off EPSCs evoked by a series of light stimuli of increasing intensity. As expected, AP-4 suppressed all On responses because of its action at On bipolar dendrites. AP-4 suppressed the Off EPSCs evoked by dim-light stimulation. In response to moderate light stimuli, Off responses in the presence of AP-4 were similar to control Off responses. As the stimulus was made brighter, Off responses were enhanced in the presence of AP-4. Similar effects were observed in eight other ganglion cells. These experiments demonstrate that the effects of mGluRs on ganglion cell Off responses are independent of this inhibitory circuitry.

To examine the role of endogenous activation of mGluRs on synaptic inputs, we measured light responses of ganglion cells in the presence of the antagonist CPPG. In these experiments, a more extensive cocktail of inhibitory antagonists was used. A combination of picrotoxin and imidazole-4-acetic acid blocked $\mathrm{GABA}_{\mathrm{A}}$ and $\mathrm{GABA}_{\mathrm{C}}$ receptors, CGP35348 blocked $\mathrm{GABA}_{\mathrm{B}}$ receptors, and strychnine blocked glycine receptors. Under these conditions, AP-4 still strongly suppressed the Off EPSCs evoked by dim-light stimuli (Fig. $9 A, B$, first row). In all six cells tested, the addition of CPPG blocked the effects of AP-4 on the Off EPSCs. In the presence of CPPG, responses to dim lights were not significantly affected in these cells (96 $\pm 12 \%$ of control) (Fig. $9 A, B$, first row). Thus, endogenous feedback was not significantly activated by weak stimuli. In two of six cells, AP-4 decreased the Off response to bright-light stimuli and CPPG reversed and enhanced the EPSC $(22 \pm 6 \%$ enhancement compared with control) (Fig. 9A, second row). This was similar to what was found in the zap experiments (Fig. $6 A$ ). However, in four of the six cells, AP-4 either enhanced or did not affect the Off response to bright light (Fig. 9B, second row). In these cells, CPPG reduced the Off EPSCs by $36 \pm 9 \%$ (Fig. 9B, second row). Thus, CPPG always enhanced ganglion cell EPSCs because of strong zap stimulation of bipolar cells, but CPPG often suppressed Off EPSCs evoked by strong light stimuli. This suggests that bright-light stimuli recruit another circuit besides the bipolar to ganglion cell connection stimulated by the zap. Nonetheless, CPPG experiments using both zap and light stimuli reveal that endogenous activation of mGluRs was only apparent with stronger stimulations.

\section{DISCUSSION}

\section{Autoreceptor feedback}

These experiments demonstrate that group III mGluRs shape bipolar cell outputs to ganglion cells. The effects of agonists and antagonists on monosynaptically evoked EPSCs recorded in ganglion cells suggest that the endogenous activation of mGluRs suppresses bipolar cell output. It is likely that these receptors function as autoreceptors and regulate bipolar cell transmitter release. 


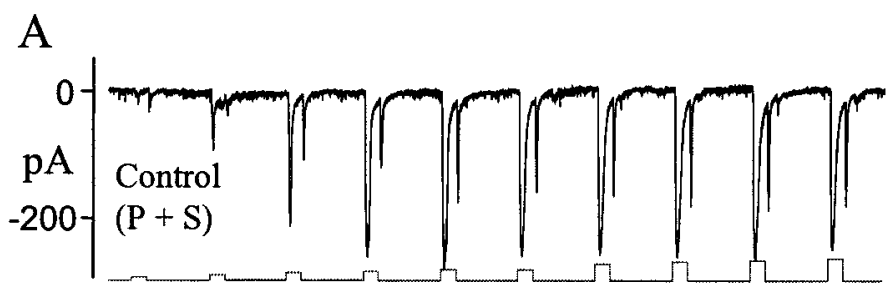

B

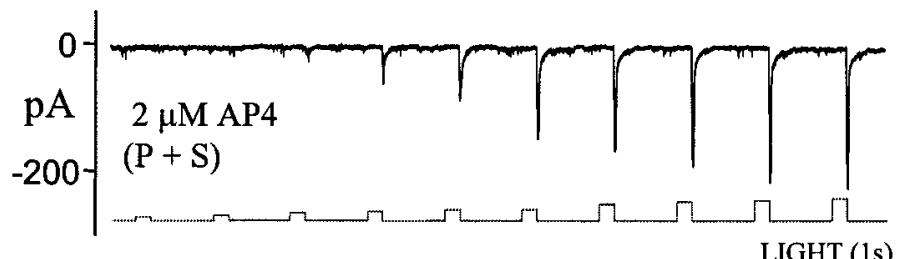

$\mathrm{C}$

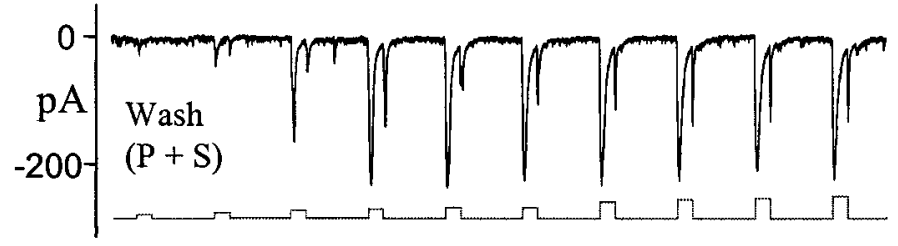

Figure 8. The actions of AP-4 do not depend on the inhibitory circuitry of the retina. All responses were recorded in the presence of $100 \mu \mathrm{M}$ picrotoxin and $10 \mu \mathrm{M}$ strychnine $(P+S)$. $A$, A series of EPSCs in a ganglion cell evoked by increasing intensities of light stimuli. Responses to the same stimuli were also recorded in the added presence of AP-4 $(B)$ and after AP-4 had been washed out $(C)$. Neurons were voltage-clamped at $-70 \mathrm{mV}\left(\mathrm{E}_{\mathrm{Cl}}\right)$.

Stimuli that produced small postsynaptic responses were strongly suppressed by AP-4 and largely unaffected by CPPG. Conversely, zap stimuli that produced large EPSCs in ganglion cells were relatively unaffected by AP-4 but enhanced by CPPG. The fact that CPPG had little effect during weak stimulation suggests that few autoreceptors were activated under these conditions. Because AP-4 had little effect during strong stimulation, mGluRs were probably saturated under these conditions. Thus, the dynamic range of the postsynaptic response is well matched to the activation of the presynaptic autoreceptors. These experiments were performed on transiently responding ganglion cells; the autoreceptor feedback may differ in sustained ganglion cells.

The correlated activation of presynaptic and postsynaptic receptors argues for a localized action at the synapse. This scenario is distinct from the proposed heterosynaptic regulation mediated by mGluR2 (Scanziani et al., 1997) at mossy fiber synapses in the hippocampus. At these synapses, mGluR2s are located far from the release site (Yokoi et al., 1996) and are stimulated by activitydependent glutamate spillover (Scanziani et al., 1997). In contrast, group III receptors are often found near synaptic release sites. The feedback receptors at the bipolar cell synapse seem to fit this group III model.

\section{Properties of the autoreceptor}

Several group III receptors have been identified in the retina. mGluR6 is localized exclusively to dendritic terminals of On bipolar cells (Nomura et al., 1994; Vardi and Morigiwa, 1997). The mGluR4 receptor has not been observed in bipolar cells of the retina (Hartveit et al., 1995; Koulen et al., 1996). The mGluR7 receptor has been localized to the bipolar cell terminal
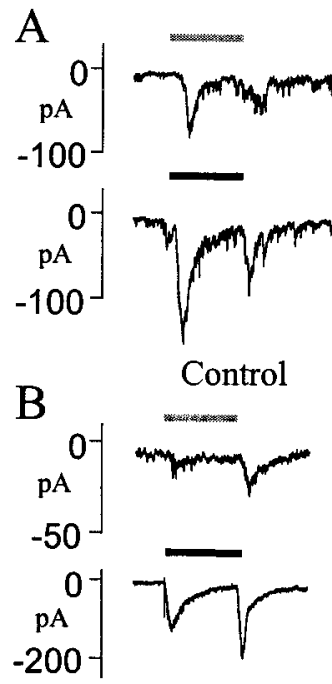
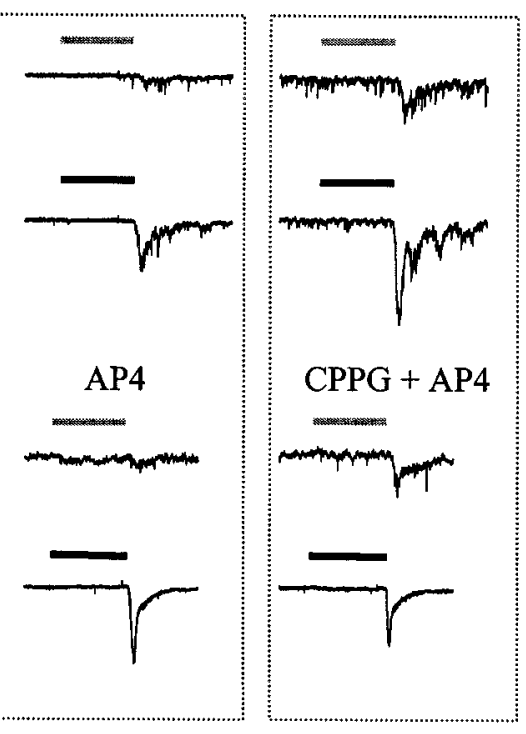

Figure 9. Bright-light stimuli activate endogenous mGluRs, but weak stimuli do not. For the two types of responses seen in ganglion cells $(A$, $B$ ), responses to dim light are shown in the top row (gray bars) of $A$ and $B$, whereas responses to bright light (black bars) are shown in the bottom row of $A$ and $B$. Responses in control (left), in $2 \mu \mathrm{M} \mathrm{AP-4} \mathrm{(middle),} \mathrm{and} \mathrm{in}$ $2 \mu \mathrm{M}$ AP-4 plus $200 \mu \mathrm{M}$ CPPG (right) are illustrated in $A$ and $B$. The solid gray bars and black bars represent $1 \mathrm{sec}(A)$ and $2 \mathrm{sec}(B)$ of red-light stimuli. Experiments were performed in the presence of $100 \mu \mathrm{M}$ picrotoxin, $10 \mu \mathrm{M}$ strychnine, and $500 \mu \mathrm{M}$ CGP35348. Neurons were voltageclamped at $-70 \mathrm{mV}\left(\mathrm{E}_{\mathrm{Cl}}\right)$.

in rat retina, in which it is found at only one side of the presynaptic dyad (Brandstätter et al., 1996). These receptors have also been found at or near the bipolar cell terminals in salamander retina (Higgs and Lukasiewicz, 2000). However, mGluR7 has a low affinity $\left(\mathrm{EC}_{50}\right.$ is $1 \mathrm{~mm}$ for glutamate and $160 \mu \mathrm{M}$ for AP-4) (Anwyl, 1999) and is thus not likely to account for the effects we have observed. mGluR8 has been localized to the inner plexiform layer and does have high affinity for AP-4. Therefore, this receptor is a potential candidate for the bipolar cell autoreceptor characterized in this study. This leaves the possibility that another, perhaps more selective, autoreceptor function is mediated by mGluR7.

Application of CPPG increased the peak of an EPSC evoked by a single test pulse. Because the EPSC peaked in $<20 \mathrm{msec}$, the endogenous autoreceptor feedback system must act within this time scale. Thus, it appears that postsynaptic and presynaptic responses are well correlated in time as well as in dynamic range. Rapid regulation by mGluRs on this time scale has been observed in neurons in the hypothalamus (Schrader and Tasker, 1997) and in the lamprey brainstem (Cochilla and Alford, 1998). It suggests a truncated transduction cascade, possibly a direct G-protein action.

\section{Metabotropic glutamate receptors regulate Off bipolar cell output}

In the dark, a continuous train of spontaneous excitatory synaptic currents is observed in ganglion cells (Tian et al., 1998; Gao and Wu, 1999). These spontaneous EPSCs, generated by glutamatergic input from bipolar cells, are more likely to originate from Off bipolar cells because these neurons are depolarized and exhibit prominent spontaneous activity in darkness, whereas On bipolar cells are hyperpolarized and are relatively quiet (Wu et al., 2000). This spontaneous activity observed in ganglion cells is dramati- 
cally reduced by AP-4, indicating that mGluRs regulate output of Off bipolar cells. Agonists of group I or group II mGluRs do not appreciably influence spontaneous EPSCs, indicating that this regulation is mediated by a group III mGluR. Consistent with this finding, AP-4 was also found to reduce the dark currents in Off ganglion cells (cells that received their inputs primarily from Off bipolar cells). Because AP-4 does not suppress the light-evoked response of Off bipolar cells, it is most likely acting at the bipolar cell axon terminal.

\section{Metabotropic glutamate receptors act at On bipolar cell axonal terminals}

To demonstrate that AP-4 regulates the output of On bipolar cells, exogenous stimulation was used. Using artificial stimulation, it was difficult to ensure that only On bipolar cells were stimulated. However, it is likely that these protocols preferentially stimulated transmitter release from On bipolar cells. In the dark, Off bipolar cells are depolarized and release transmitter. On bipolar cells are hyperpolarized and release very little transmitter. The zaps and $\mathrm{K}^{+}$puffs used depolarize both types of bipolar cells, but the incremental transmitter release should be greater for the On bipolar cell. Consistent with this proposition, exogenous stimulation of bipolar cells just before a light stimulus depressed On more than Off responses (Yu and Miller, 1995). Direct depolarization of bipolar cells, using puffs of high potassium in the outer plexiform layer, initiated EPSCs in ganglion cells. These EPSCs were suppressed by AP-4, indicating that AP-4 acted directly on the bipolar cell to reduce its output to ganglion cells. Similarly, sucrose puffs in the inner plexiform layer produced EPSCs in ganglion cells, and these responses could also be suppressed by AP-4. Together, these data suggest that AP-4 is acting at the On bipolar cell synaptic terminals.

\section{Other mGluR pathways may influence the light responses}

Because AP-4 suppressed spontaneous activity, it was anticipated that it would also reduce the light-evoked EPSCs in ganglion cells. AP-4 blocks On light responses because of an action at On bipolar dendrites, so only the Off bipolar input to ganglion cells could be analyzed. The Off EPSC was consistently suppressed when weak to moderate (nonsaturating) light stimuli were used. The effects of AP-4 on responses to nonsaturating light stimuli were similar to our other experimental protocols (potassium, sucrose, current stimuli, and spontaneous activity) and could be interpreted as a simple suppression at the Off bipolar cell axon terminal. However, an additional effect of AP-4 at the photoreceptors (Koulen et al., 1999) cannot be ruled out. The effects of AP-4 on responses to bright light were more variable. In some neurons, the EPSC was decreased by AP-4. In these cells, CPPG enhanced the responses to strong light stimulation. However, in many neurons, AP-4 did not alter or even enhanced the Off responses, as reported previously (Arkin and Miller, 1987). In these cases, CPPG suppressed the Off EPSC. In every case, the action of CPPG was opposite to that of AP-4, indicating that these varied effects of AP-4 represent a specific action on mGluRs. Because AP-4 consistently suppressed the ganglion cell EPSCs produced by direct bipolar cell stimulation, spontaneous EPSCs, and dim light, it is likely that the AP-4 enhancement during bright-light stimuli activates another part of the retinal network.

A likely candidate is the rod input to the Off bipolar cell. Hare and Owen (1992) found that AP-4 enhanced rod input to Off bipolar cells. A red LED stimulus was used in our experiments. This preferentially stimulates cones, such that dim-light intensities had a very small effect on rods. Strong red LED stimulation was required to vigorously stimulate rods. Therefore, the AP-4 enhancement of Off responses is likely the result of an augmented rod component that is only evident during strong light stimulation.

\section{Physiological implications}

Functionally, the autoreceptor feedback may extend the dynamic range of the bipolar cell output synapse. Weak stimuli evoke little feedback (based on the small CPPG effect). Strong signals that might saturate the bipolar cell output do not do so because of the negative feedback (based on enhancement of strong zaps by CPPG). This permits an increase in output range. An interesting extension of this concept is that the mGluR may allow for potentiation of bipolar cell output. If the mGluR is suppressed, then the output of the bipolar cell will be enhanced, particularly to moderate and strong light stimuli. The bipolar cell output can be potentiated by protein kinase C (Minami et al., 1998). Protein kinase C can suppress group III mGluRs (Macek et al., 1999). This suggests a possible mechanism in which protein kinase $\mathrm{C}$ inhibits the mGluR, thereby potentiating the output of bipolar cells. Thus, the gain of the bipolar to ganglion cell synapse might be controlled by factors in the inner retina that regulate autoreceptor feedback.

\section{REFERENCES}

Anwyl R (1999) Metabotropic glutamate receptors: electrophysiological properties and role in plasticity. Brain Res Brain Res Rev 29:83-120.

Arkin MS, Miller RF (1987) Subtle actions of 2-amino-4phosphonobutyrate (APB) on the Off pathway in the mudpuppy retina. Brain Res 426:142-148.

Asztely F, Erdemli G, Kullmann DM (1997) Extrasynaptic glutamate spillover in the hippocampus: dependence on temperature and the role of active glutamate uptake. Neuron 18:281-293.

Awatramani GB, Slaughter MM (2000) Origin of transient and sustained responses in ganglion cells of the retina. J Neurosci 20:7087-7095.

Brandstätter JH, Koulen P, Kuhn R, van der Putten H, Wässle H (1996) Compartmental localization of a metabotropic glutamate receptor (mGluR7): two different active sites at a retinal synapse. J Neurosci 16:4749-4756.

Cochilla AJ, Alford S (1998) Metabotropic glutamate receptormediated control of neurotransmitter release. Neuron 20:1007-1016.

Diamond JS, Copenhagen DR (1995) The relationship between lightevoked synaptic excitation and spiking behaviour of salamander retinal ganglion cells. J Physiol (Lond) 487:711-725.

Dube GR, Marshall KC (2000) Activity-dependent activation of presynaptic metabotropic glutamate receptors in locus coeruleus. J Neurophysiol 83:1141-1149.

Gao F, Wu SM (1999) Multiple types of spontaneous excitatory synaptic currents in salamander retinal ganglion cells. Brain Res 821:487-502.

Hare WA, Owen WG (1992) Effects of 2-amino-4-phosphonobutyric acid on cells in the distal layers of the tiger salamander's retina. J Physiol (Lond) 445:741-757.

Hartveit E, Brandstätter JH, Enz R, Wässle H (1995) Expression of the mRNA of seven metabotropic glutamate receptors (mGluR1 to 7) in the rat retina: an in situ hybridization study on tissue sections and isolated cells. Eur J Neurosci 7:1472-1483.

Hayashi Y, Momiyama A, Takahashi T, Ohishi H, Ogawa-Meguro R, Shigemoto R, Mizuno N, Nakanishi S (1993) Role of a metabotropic glutamate receptor in synaptic modulation in the accessory olfactory bulb. Nature 366:687-690.

Higgs MH, Lukasiewicz PD (1999) Glutamate uptake limits synaptic excitation of retinal ganglion cells. J Neurosci 19:3691-3700.

Higgs MH, Lukasiewicz PD (2000) Group III metabotropic glutamate receptors inhibit glutamate release from retinal bipolar cell. Invest Ophthalmol Vis Sci 41:621.

Jane DE, Thomas NK, Tse HW, Watkins JC (1996) Potent antagonists at the L-AP4- and $(1 S, 3 S)$-ACPD-sensitive presynaptic metabotropic glutamate receptors in the neonatal rat spinal cord. Neuropharmacology 35:1029-1035.

Koulen P, Malitschek B, Kuhn R, Wässle H, Brandstätter JH (1996) Group II and group III metabotropic glutamate receptors in the rat 
retina: distributions and developmental expression patterns. Eur J Neurosci 8:2177-2187.

Koulen P, Kuhn R, Wässle H, Brändstatter JH (1997) Group I metabotropic glutamate receptors mGluR1 $\alpha$ and mGluR5a: localization in both synaptic layers of the rat retina. J Neurosci 17:2200-2211.

Koulen P, Kuhn R, Wässle H, Brandstätter JH (1999) Modulation of the intracellular calcium concentration in photoreceptor terminals by a presynaptic metabotropic glutamate receptor. Proc Natl Acad Sci USA 96:9909-9914.

Li H, Ohishi H, Kinoshita A, Shigemoto R, Nomura S, Mizuno N (1997) Localization of a metabotropic glutamate receptor, mGluR7, in axon terminals of presumed nociceptive, primary afferent fibers in the superficial layers of the spinal dorsal horn: an electron microscope study in the rat. Neurosci Lett 223:153-156.

Lujan R, Roberts JD, Shigemoto R, Ohishi H, Somogyi P (1997) Differential plasma membrane distribution of metabotropic glutamate receptors $\mathrm{mGluR} 1 \alpha$, mGluR2, and mGluR5, relative to neurotransmitter release sites. J Chem Neuroanat 13:219-241.

Macek TA, Schaffhauser H, Conn PJ (1999) Activation of PKC disrupts presynaptic inhibition by group II and group III metabotropic glutamate receptors and uncouples the receptor from GTP-binding proteins. Ann NY Acad Sci 868:554-557.

Maki R, Robinson MB, Dichter MA (1994) The glutamate uptake inhibitor L-trans-pyrrolidine-2,4-dicarboxylate depresses excitatory synaptic transmission via a presynaptic mechanism in cultured hippocampal neurons. J Neurosci 14:6754-6762.

Martin LJ, Blackstone CD, Huganir RL, Price DL (1992) Cellular localization of a metabotropic glutamate receptor in rat brain. Neuron 9:259-270.

Miller RJ (1998) Presynaptic receptors. Annu Rev Pharmacol Toxicol 38:201-227.

Minami N, Berglund K, Sakaba T, Kohmoto H, Tachibana M (1998) Potentiation of transmitter release by protein kinase $\mathrm{C}$ in goldfish retinal bipolar cells. J Physiol (Lond) 512:219-225.

Nomura A, Shigemoto R, Nakamura Y, Okamoto N, Mizuno N, Nakanishi S (1994) Developmentally regulated postsynaptic localization of a metabotropic glutamate receptor in rat rod bipolar cells. Cell 77:361-369

Nygaard RW, Frumkes TE (1982) LEDs: convenient, inexpensive sources for visual experimentation. Vision Res 22:435-440.

O'Donovan MJ (1999) The origin of spontaneous activity in developing networks of the vertebrate nervous system. Curr Opin Neurobiol 9:94-104.

Peng Y (1996) Ryanodine-sensitive component of calcium transients evoked by nerve firing at presynaptic nerve terminals. J Neurosci 16:6703-6712.

Petralia RS, Wang YX, Niedzielski AS, Wenthold RJ (1996) The metabotropic glutamate receptors, mGluR2 and mGluR3, show unique postsynaptic, presynaptic and glial localizations. Neuroscience 71:949-976.

Pin JP, Duvoisin R (1995) The metabotropic glutamate receptors: structure and functions. Neuropharmacology 34:1-26.

Saugstad JA, Segerson TP, Westbrook GL (1996) Metabotropic glutamate receptors activate G-protein-coupled inwardly rectifying potassium channels in Xenopus oocytes. J Neurosci 16:5979-5985.

Scanziani M, Gahwiler BH, Thompson SM (1995) Presynaptic inhibition of excitatory synaptic transmission by muscarinic and metabotropic glutamate receptor activation in the hippocampus: are $\mathrm{Ca}^{2+}$ channels involved? Neuropharmacology 34:1549-1557.

Scanziani M, Salin PA, Vogt KE, Malenka RC, Nicoll RA (1997) Usedependent increases in glutamate concentration activate presynaptic metabotropic glutamate receptors. Nature 385:630-634.

Schrader LA, Tasker JG (1997) Presynaptic modulation by metabotropic glutamate receptors of excitatory and inhibitory synaptic inputs to hypothalamic magnocellular neurons. J Neurophysiol 77:527-536.

Shen J, Watanabe S, Kaneko A (1995) Cell dissociation with papain reduces the density of cGMP-activated channels of the retinal rod. Jpn J Physiol 45:151-164.

Shen W, Slaughter MM (1998) Metabotropic and ionotropic glutamate receptors regulate calcium channel currents in salamander retinal ganglion cells. J Physiol (Lond) 510:815-828.

Shiells RA, Falk G, Naghshineh S (1981) Action of glutamate and aspartate analogues on rod horizontal and bipolar cells. Nature 294:592-594.

Shigemoto R, Kulik A, Roberts JD, Ohishi H, Nusser Z, Kaneko T, Somogyi P (1996) Target-cell-specific concentration of a metabotropic glutamate receptor in the presynaptic active zone. Nature 381:523-525.

Shigemoto R, Kinoshita A, Wada E, Nomura S, Ohishi H, Takada M, Flor PJ, Neki A, Abe T, Nakanishi S, Mizuno N (1997) Differential presynaptic localization of metabotropic glutamate receptor subtypes in the rat hippocampus. J Neurosci 17:7503-7522.

Slaughter MM, Miller RF (1981) 2-amino-4-phosphonobutyric acid: a new pharmacological tool for retina research. Science 211:182-185.

Takahashi T, Forsythe ID, Tsujimoto T, Barnes-Davies M, Onodera K (1996) Presynaptic calcium current modulation by a metabotropic glutamate receptor. Science 274:594-597.

Tanabe Y, Nomura A, Masu M, Shigemoto R, Mizuno N, Nakanishi S (1993) Signal transduction, pharmacological properties, and expression patterns of two rat metabotropic glutamate receptors, mGluR3 and mGluR4. J Neurosci 13:1372-1378.

Tauchi M, Yang X, Kaneko A (1984) Depolarizing responses of L-type external horizontal cells in the goldfish retina under intense chromatic background. Vision Res 24:867-870.

Taylor WR, Chen E, Copenhagen DR (1995) Characterization of spontaneous excitatory synaptic currents in salamander retinal ganglion cells. J Physiol (Lond) 486:207-221.

Tian N, Hwang TN, Copenhagen DR (1998) Analysis of excitatory and inhibitory spontaneous synaptic activity in mouse retinal ganglion cells. J Neurophysiol 80:1327-1340.

Vardi N, Morigiwa K (1997) ON cone bipolar cells in rat express the metabotropic receptor mGluR6. Vis Neurosci 14:789-794.

Wu SM (1987) Synaptic connections between neurons in living slices of the larval tiger salamander retina. J Neurosci Methods 20:139-149.

Wu SM, Gao F, Maple BR (2000) Functional architecture of synapses in the inner retina: segregation of visual signals by stratification of bipolar cell axon terminals. J Neurosci 20:4462-4470.

Yokoi M, Kobayashi K, Manabe T, Takahashi T, Sakaguchi I, Katsuura G, Shigemoto R, Ohishi H, Nomura S, Nakamura K, Nakao K, Katsuki M, Nakanishi S (1996) Impairment of hippocampal mossy fiber LTD in mice lacking mGluR2. Science 273:645-647.

$\mathrm{Yu}$ W, Miller RF (1995) Hyperosmotic activation of transmitter release from presynaptic terminals onto retinal ganglion cells. J Neurosci Methods 62:159-168. 